\title{
Factors Influencing the Usage of an Electronic Book Collection: Size of the E-book Collection, the Student Population, and the Faculty Population
}

\section{Alain R. Lamothe}

This paper presents the results of a quantitative and systematic investigation exploring online e-book usage at the J.N. Desmarais Library of Laurentian University over a 9-year period. The size of an e-book collection was determined to show evidence of an extremely strong relationship with the level of usage e-books experienced. Of all factors examined during the course of this study, it was the size of the collection that exhibited the strongest association to usage levels and would suggest just how important the size and content of a collection can be to patron acceptance and utilization. Of all student academic levels, doctoral students exhibited the strongest relationship with e-book usage, while undergraduate students showed signs of the weakest. Faculty demonstrated the overall weakest relationship with e-book usage.

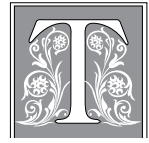

he number of electronic books available to the Laurentian University community in 2010 was a little under 80,000 , with expenditures amounting to $\$ 132,860$ (CDN\$). This represented about 25 percent of the library's overall book spending. Furthermore, electronic books currently represent 15 percent of all book titles held by the library. This is quite similar to the 13 percent observed in CARL libraries. ${ }^{2}$ Electronic book expenditures also represented 5.5 percent of the library's total acquisition budget, which is also very close to that reported by other libraries. ${ }^{3}$
The J.N. Desmarais Library has been exclusively purchasing web-based ebooks. Web-based e-books do not necessitate the purchase of any special viewing devices. Access to the web and a web browser are their only requirements. Consequently, web-based books are extremely appealing to libraries. ${ }^{4}$ Not only have patrons and library personnel alike been frustrated with the operation of reading devices, each type of device also comes with an extra cost associated with their purchase as well as staff training: time and money not required for the operation of simple web browsers. ${ }^{5}$ 
J.N. Desmarais Library patrons are given access to the collection's e-books by two means. Links to the various e-book packages are displayed on the library's website. These links are added immediately after access has been granted. Studies have confirmed that library websites are critical e-book access points and, for the majority of undergraduate students, the primary e-book discovery tool. ${ }^{6}$ In addition to web links, catalogue records are added for every title. The addition of bibliographic records for each e-book has been demonstrated to significantly increase use. ${ }^{7}$ Faculty and, particularly, graduate students rely heavily upon the library's catalogue to locate and access ebooks. ${ }^{8}$ Some libraries have even observed a doubling in usage. ${ }^{9}$ The length of time required to catalogue new e-books at the J.N. Desmarais Library will vary according to the number of books purchased at any one time as well as the availability of pre-existing MARC records. For these reasons, e-books purchased individually can be immediately catalogued, but cataloguing bundled titles can take anywhere from one week to six months.

\section{Methods}

There has been much confusion throughout the literature regarding the definition of an electronic book. Both definition and descriptive term have varied throughout the years, with e-book or ebook, electronic book, electronic text, or even e-text being commonly used. ${ }^{10}$ To avoid reader confusion that such variations have often caused, the term "e-book" will be strictly and consistently used throughout this paper.

The definition of an e-book has varied even more, with many considering e-books as simply being the content of printed books reproduced digitally, either in PDF, text, or other web-compatible formats. ${ }^{11}$ Publishers predominantly consider e-books to be just that. ${ }^{12}$ Some e-books are created digitally and cannot be practically converted back into print. ${ }^{13}$ E-books are available in several formats: web-based, reader-based (such as Kindle) or device-based (examples: PDAs, iPhones, Android smartphones). The majority, however, are web-based..$^{14}$ Furthermore, e-books include textbooks, picture books, audiobooks, and multimedia books. ${ }^{15}$ Other researchers have insisted that the term e-book should refer to the technology, both hardware and software, involved in the display of the electronic text and not to the text itself. ${ }^{16}$ At the J.N. Desmarais Library, the simplest and most common definition of an e-book was adopted: a literal digital reproduction of a printed book.

The number of e-books was obtained by count. Numbers included all titles purchased individually from aggregators such as NetLibrary and MyiLibrary as well as publishers like Britannica, Gale, Johns Hopkins University Press, and Wiley. E-book packages were acquired directly from APA, Cambridge University Press, Duke University Press, Elsevier, Emerald, IEEE, Proquest, OECD, Ovid, Oxford University Press, Sage, Springer, and Taylor \& Francis. Changes in the number of e-books were monitored to determine the existence and strength of a relationship between use and the size of the e-book collection.

Annual student and faculty numbers were obtain from Laurentian University's Institutional Planning Office ${ }^{17}$ and were available from 2002 onward. Student numbers were not only available for the total population but also for each academic level, undergraduate and graduate students alike.

In addition to the number of e-books, statistics tracked included the number of viewings and the number of searches performed on publisher and aggregator sites. It was decided to report the number of searches and not that of sessions since searches are a more accurate method of measuring usage as they correspond to a deliberate action on the part of a patron. ${ }^{18}$ It is important to note that searches for ebooks performed from the library's online catalogue were unavailable and, thus, not 
included in this study. Searches performed on vendor sites were strictly reported.

For the purpose of this study, a viewing has been defined as the act of either opening or downloading a page or chapter from an e-book. E-book publishers and aggregators have reported usages as accesses, downloads, or viewings. Furthermore, accesses, downloads, or viewings have been reported per page, per chapter, or per book. Accesses reported for each page of a book viewed can artificially inflate usage. Conversely, reporting an access per book regardless of how many pages have been viewed can have the opposite effect and suppress real usage. There is, obviously, just as much confusion over the reporting of e-book usage statistics as there is over its name and definition.

Ratios were calculated to compare usage to the size of the e-book collection. The number of viewings divided by the number of e-books (\# viewings / \# ebooks) provided a "viewings per e-book" ratio. Similarly, the number of searches divided by the number of e-books (\# searches / \# e-books) yielded a "search per e-book" ratio. And, finally, dividing the number of viewings by the number of searches (\# viewings / \# searches) gave a "viewings per search" ratio. Ratios allow for the control of extraneous factors, such as population size. ${ }^{19}$ In the case of this study, the size of the e-book collection can be understood to constitute a population. All ratios were expressed in decimal form.

The "viewings per e-book" and "searches per e-book" ratios can give a comparative indication of the level of use of a particular collection for any given period of time. The greater the value of the ratio calculated, the greater the relative use. It is also very important to note that such a ratio should never be interpreted as representing actual usage per e-book but rather as a relative or comparative value. For instance, a "viewings per e-book" ratio of 15 should never be interpreted as meaning that each e-book in a collection was viewed 15 times.
Pearson product-moment correlation coefficients, often referred to as coefficients of association, were calculated to determine the linear dependency between two variables. ${ }^{20}$ Coefficients were calculated to measure the strength of the relationship between searches and e-books, viewings and e-books, viewings and searches, searches and student numbers, viewings and student numbers, searches and faculty numbers, and, finally, viewings and faculty numbers. It is also important to note that a correlation coefficient measures the strength of association between two variables but does not identify which of the variables may be responsible for changes observed in the other. ${ }^{21}$

Finally, a Student's t-Test was performed to test for any statistically significant difference between the number of viewings and the number of searches.

\section{Results and Discussion}

\section{Evolution of the J.N. Desmarais Library's E-book Collection}

The evolution of the J.N. Desmarais Library's e-book collection experienced four distinctive phases of growth defined by method of purchase (see table 1).

\begin{tabular}{|c|c|c|c|}
\hline \multicolumn{4}{|c|}{$\begin{array}{c}\text { TABLE } 1 \\
\text { Change in the Number of Titles } \\
\text { Comprising the E-book Collection } \\
\text { at Laurentian University along } \\
\text { with the Percent Change in } \\
\text { Growth, over a 9-Year Period }\end{array}$} \\
\hline Year & E-books & $\begin{array}{c}\% \\
\text { Growth }\end{array}$ & $\begin{array}{c}\text { Phases of } \\
\text { Growth }\end{array}$ \\
\hline 2002 & 1 & $\mathrm{~N} / \mathrm{A}$ & \multirow{3}{*}{ Phase 1} \\
\hline 2003 & 3,426 & 3,426 & \\
\hline 2004 & 9,229 & 169 & \\
\hline 2005 & 11,433 & 24 & \multirow{3}{*}{ Phase 2} \\
\hline 2006 & 12,130 & 6 & \\
\hline 2007 & 15,510 & 28 & \\
\hline 2008 & 60,264 & 289 & Phase 3 \\
\hline 2009 & 74,264 & 23 & \multirow{2}{*}{ Phase 4} \\
\hline 2010 & 79,821 & 8 & \\
\hline
\end{tabular}


The first phase occurred between 2002 and 2004 when the library began the process of building its e-book collection. It is the period in which the collection experienced the greatest level of growth in size, with a 3,426 percent increase in the number of e-books relative to the previous year. In 2002, the library had purchased a single e-book: the Encyclopedia Britannica Online; during the following year, it added the COOL I collection of 3,425 e-books from NetLibrary. COOL (Consortium of Ontario Libraries) is a library consortium created in 1998 and based in the Province of Ontario, Canada. COOL represents public, university, college, and school library interests by negotiating license agreements with service providers, particularly for online resources. ${ }^{22}$ The following year, the purchase of a second COOL negotiated e-book package from NetLibrary (COOL II collection) brought the total number of e-books available to the Laurentian community to 9,229.

During the second phase, the e-book collection continued to grow, but at a very different pace (see table 1 ). The collection continued to increase at a steady and much slower rate. During this phase, e-books were not purchased in large bundles but rather on a title-by-title basis directly from Netlibrary, from the Gale Virtual Reference Library, and from the Oxford Digital Reference Shelf. Focus was placed on individual program needs and faculty requests.

In 2008, the library returned to the aggressive purchase of e-books in large bundles, this time directly from publishers rather than an aggregator. Consequently, phase 3 saw the addition of nearly 45,000 new electronic titles. By the end of that year, the total number of e-books available to the Laurentian community had suddenly risen sharply to 60,264 , a 289 percent increase in collection size (see table 1). As with the initial COOL purchases, these e-book packages were also acquired through consortia, in particular OCUL (Ontario Council of University Libraries) and CRKN (Canadian Research Knowledge Network). OCUL represents the 21 academic libraries in the Province of Ontario, Canada, and concerns "itself with the improvement and development of university library resources." ${ }^{23} \mathrm{CRKN}$ is an even larger consortium with $73 \mathrm{Ca}$ nadian universities and is mandated to negotiate the purchase of "digital content for the academic research enterprise." ${ }^{24}$

During phase 4, the J.N. Desmarais Library adopted a mixed approach to

\begin{tabular}{|c|c|c|c|c|c|}
\hline \multicolumn{6}{|c|}{$\begin{array}{c}\text { TABLE } 2 \\
\text { Change in the Number of E-books at Laurentian University, the Number of } \\
\text { Searches Performed on E-book Vendor Search Engines and the Number of } \\
\text { Viewings over a 9-Year Period }\end{array}$} \\
\hline Year & E-books & Searches & $\begin{array}{l}\text { \% Growth } \\
\text { in Searches }\end{array}$ & Viewings & $\begin{array}{l}\text { \% Growth } \\
\text { in Viewings }\end{array}$ \\
\hline 2002 & 1 & 1,841 & N/A & 2,246 & N/A \\
\hline 2003 & 3,426 & 3,368 & 83 & 4,512 & 101 \\
\hline 2004 & 9,229 & 11,625 & 245 & 12,173 & 170 \\
\hline 2005 & 11,433 & 22,190 & 91 & 43,269 & 255 \\
\hline 2006 & 12,130 & 39,876 & 80 & 44,345 & 25 \\
\hline 2007 & 15,510 & 51,798 & 30 & 48,174 & 9 \\
\hline 2008 & 60,264 & 101,262 & 95 & 71,226 & 48 \\
\hline 2009 & 74,264 & 109,693 & 8 & 269,926 & 279 \\
\hline 2010 & 79,821 & 102,623 & -6 & 250,303 & -7 \\
\hline
\end{tabular}


purchasing e-books. It continued to acquire consortially negotiated academic e-book packages but also returned to the individual purchase of titles from an aggregator. By the end of 2010, the ebook collection included a total of 79,821 individual books.

\section{Analysis of the Usage Metrics: Viewings and Searches}

It is clear that the e-book collection at the J.N. Desmarais Library has been substantially used, particularly in recent years, with an accumulated total of 750,000 viewings and 430,000 searches (see table 2). During the first seven years, the number of viewings and the number of searches increased steadily, almost linearly (see figure 1). Similar steady annual increases in e-book usage occurred at other institutions over the same years. ${ }^{25}$ An exponential increase in viewings followed, matching the period in which nearly 30,000 SpringerLink books were purchased and added to the library's col- lection (see table 2 and figure 1). Surprisingly, Harris also noted an exponential 119 percent increase in SpringerLink ebook downloads between 2007 and 2009. ${ }^{26}$ The following year experienced a slight 7 percent decrease in viewings despite the addition of 5,557 e-books. It is interesting to observe that the rate of collection growth closely matched the decrease in usage with an 8 percent expansion (see table 1).

There also appeared to be a similarity between the curve representing the number of viewings and the curve representing the number of searches, hinting to a possible close relationship. In fact, the calculation of a Pearson's correlation coefficient of $r=0.80$ suggested a strong relationship between both variables. The act of searching within an e-book collection could have exerted an influence on the number of viewings if each search yielded multiple full-text content and, consequently, a greater number of viewings. On the other hand, the act of

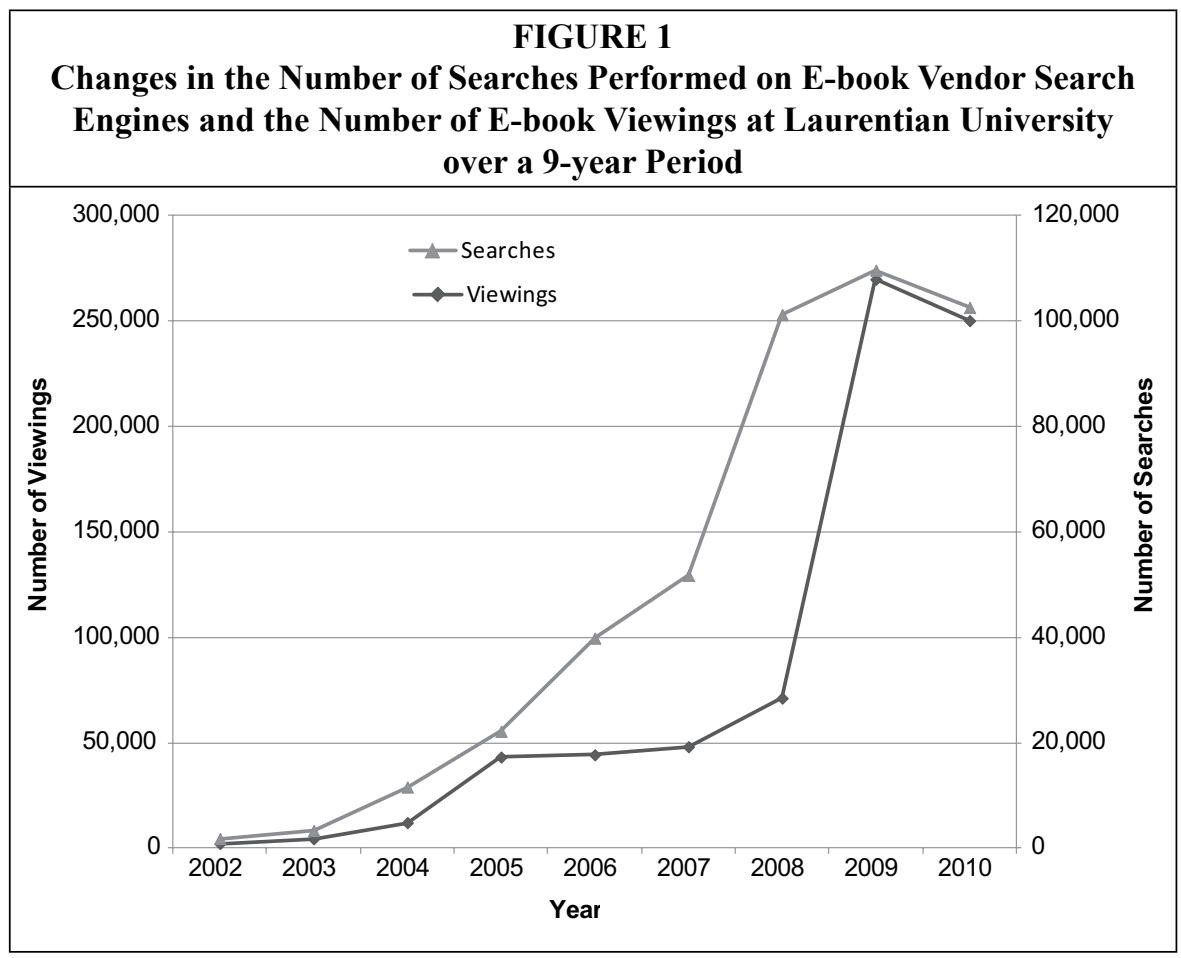


finding relevant full-text content may have encouraged patrons to perform additional searches.

Because of the relatively high correlation coefficient, a Student's t-Test was performed to test for any significant difference between searches and viewings (see table 2). There was no statistical difference between the variables $\left(t=0.383\right.$ and $t_{0.05(2), 8}$ $=2.306$ ). Analysis of e-book usage could potentially rely on searches rather than the more traditional viewings, or downloads, to measure activity. It was stated earlier that publishers have yet to adopt any formal standard for reporting download-based usage. Therefore, employing searches as a usage metric may produce far more consistent and accurate results. On the other hand, the true value of e-book usage comes from full-text downloads, as they reflect what patrons do with the information they find. It would be interesting if parallel analyses on e-book usage at other institutions would yield similar results and associations.
Examining the Impact of the Size of the Ebook Collection on Viewings and Searches As demonstrated in figure 2, the number of viewings had increased annually at a similar rate to the increase in the number of e-books. The curves graphed for both variables follow each other quite closely. A Pearson's correlation coefficient of $\mathrm{r}=0.91$ further supported the existence of a very strong relationship between viewings and the number of e-books. A similar closeness of the curves representing searches and the number of e-books was confirmed by an equally strong relationship $(r=0.96$; see figure 3 ). The level of usage appeared to be directly proportional to the size of the collection. Larger collections may lead to a greater number of viewings and searches. Alternatively, perhaps a high level of usage encouraged the library to purchase even more e-books.

In 2002, the single e-book held by the J.N. Desmarais Library (Encyclopedia Britannica Online) recorded 2,246 viewings and 1,841 searches. Between 2003 and

FIGURE 2

Changes in the Number of E-book Viewings Compared to Changes in the Number of E-books Available at Laurentian University over a 9-year Period

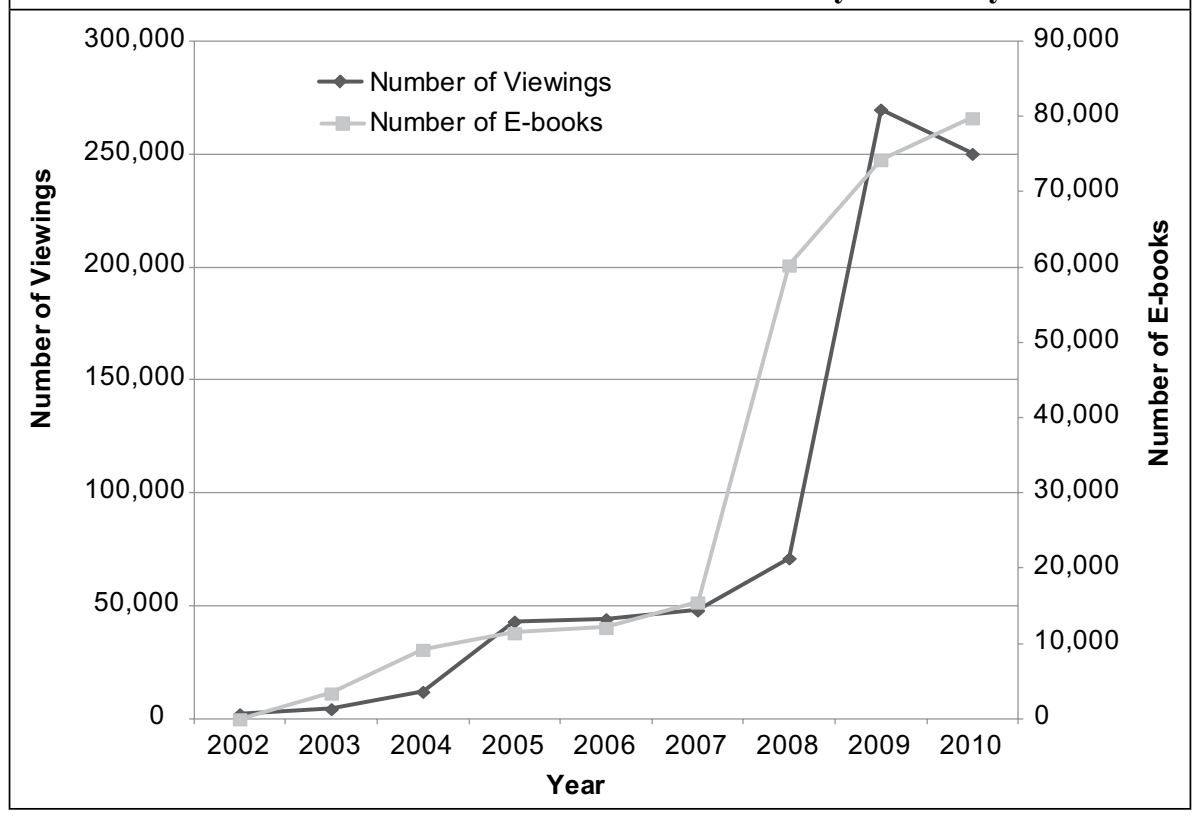




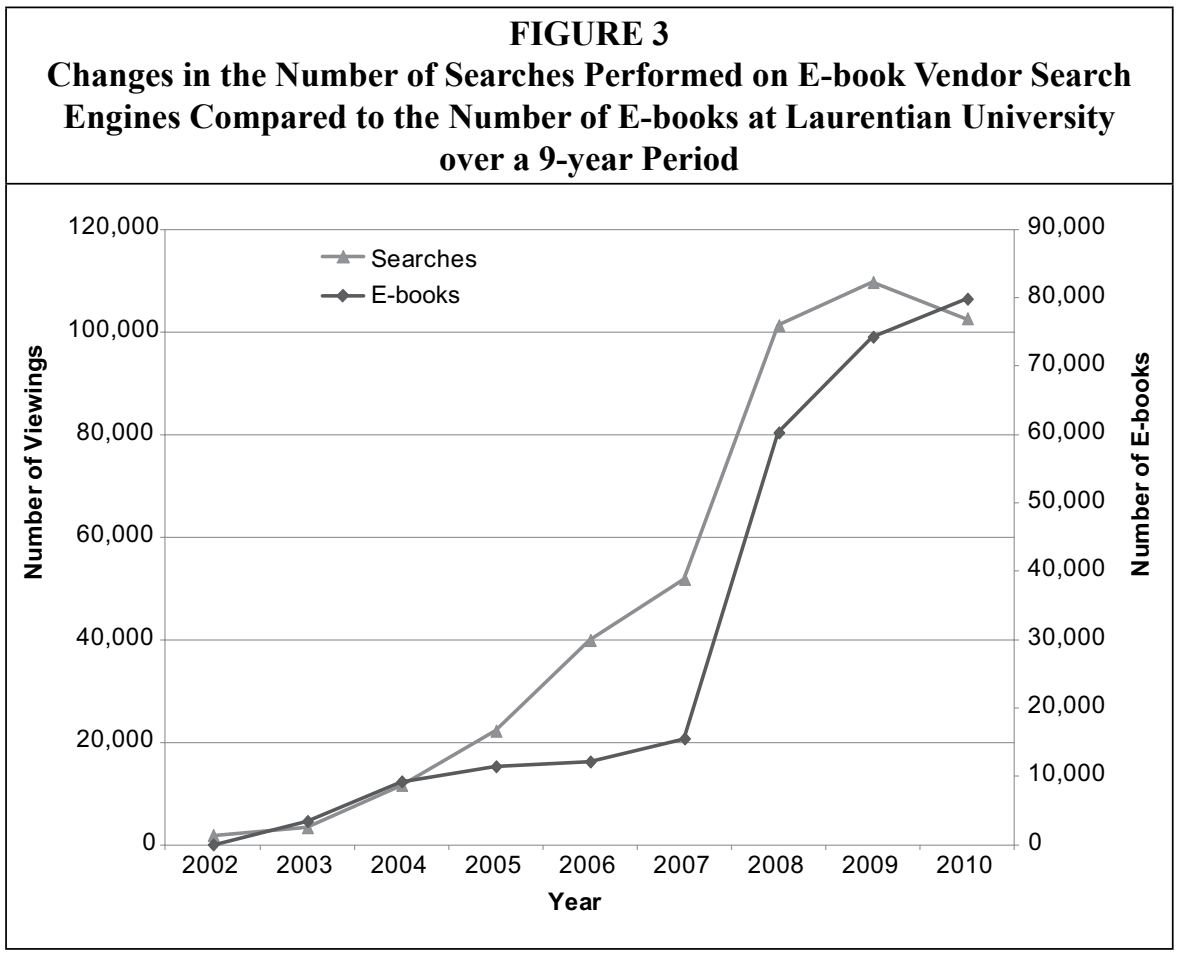

2004, after the addition of both COOL packages, the number of viewings and searches closely matched the number of books (see table 2). Relatively speaking, this represented far fewer viewings and searches per e-book. In addition, this phase of collection building is the only phase in which searches and viewings closely matched e-books in numbers (see table 2). In 2003, the COOL collection recorded no viewings whatsoever and only 637 in 2004 . On the other hand, the Encyclopedia Britannica Online recorded 4,512 viewings in 2003 and 11,536 in 2004, in a clear demonstration of demand for at least certain e-books.

It was determined that the contents of both COOL I and COOL II deals were more appropriate for public library patrons and were not experiencing a significant amount of viewings at Laurentian University. Public libraries comprised 65 percent of the COOL membership, with all participants selecting e-book titles to be included. ${ }^{27}$ As a result, these collec- tions were not addressing Laurentian's academic requirements. Other similar consortial arrangements have yielded identical results, with very few titles of use or interest to academic patrons. ${ }^{28} \mathrm{E}$ books purchased on a title-by-title basis have experienced greater rates of use than those purchased through large aggregated collections. ${ }^{29}$

In 2005, viewings had nearly quadrupled in number compared to the previous year (see table 2). This increase of 255 percent in the number of viewings surpassed the 24 percent increase in the number of e-books. Usage grew faster than the size of the collection. Upon further examination, it was observed that the e-books individually purchased from NetLibrary as well as those on the Gale Virtual Reference Library and Oxford Digital Reference Shelf were seeing the greatest number of viewings. Both 2006 and 2007 experienced the smallest increase in viewings compared to the prior year $(2.4 \%$ and $1.0 \%$, respectively). Usage appeared to be leveling off into a 
graphical plateau phase. But the sudden 289 percent increase in the number of e-books in 2008 was accompanied by a 48 percent increase in viewings and a 95 percent increase in searches (see table 2).

Several authors have observed a greater level of usage after an e-book collection had gained acceptance upon reaching a critical mass in which students and faculty begin to find more and more relevant information. ${ }^{30}$ The very high correlation coefficients reported for viewings $(r=0.91)$ and searches $(r=0.96)$ lend support to these previous findings. There is an extremely strong link between the size of an e-book collection and the level of usage. It is also clear from figure 2 and figure 3 that, after the substantial increase in viewings and searches observed in 2008 , usage for the subsequent years had somewhat leveled off again. It is quite possible that the J.N. Desmarais Library e-book collection had reached a critical mass in and around 2008.

More improved and effective search engines on publisher and aggregator websites may have influenced the increase in the number of searches. ${ }^{31}$ Grogg and Ashmore ${ }^{32}$ concluded that any collection of e-books with an efficient search engine embedded within would see increased use and, consequently, increased value. Having the ability to search not only across the chapters of a particular e-book but also across an entire e-book collection has been demonstrated to be an asset to patrons. ${ }^{33}$ A well-structured platform with easily identified search features would encourage patrons to return time and again for further investigation. ${ }^{34}$ In fact, the searchability of e-books has been identified as being one of their most significant benefits, ${ }^{35}$ especially if the option of searching by keyword or subject term was available. ${ }^{36}$

Both ScienceDirect and SpringerLink are sites that have greatly improved access to their e-book content, making them far more appealing to patrons who do return to search for additional relevant content. ${ }^{37}$ It was also in 2008 that the library purchased over 500 ScienceDirect and nearly 30,000 SpringerLink titles.

Additionally, a University of Rochester study reported in 2001 that nearly 65 percent of their patrons had experienced difficulties with the NetLibary e-book platform. ${ }^{38}$ It was in this period of time that the J.N. Desmarais Library had purchased its first NetLibrary e-books. Herlihy and $\mathrm{Yi}^{39}$ also reported a steady decline in NetLibrary e-books usage over a 5-year period, whereas Safari e-books usage rose. They suggested that perhaps currency of the material had an impact on usage since their Safari content was regularly updated while their NetLibrary holdings remained static. At the J.N. Desmarais Library, NetLibrary holdings have also been static for the past 5 years as individual e-book titles are now purchased on a title-by-title basis strictly from MyiLibrary. A combination of unintuitive search platform and inappropriate and static content could have contributed to the low usage experienced by the library's NetLibrary content.

Complementary information pertaining to the "viewings per e-book" and the "searches per e-book" ratios is provided in table 3. Ratios are an easily calculated estimate comparing relative use. A low

\section{TABLE 3}

Viewings per E-book, Searches per Ebook and Viewings per Search Ratios

\begin{tabular}{|c|c|c|c|}
\hline Year & $\begin{array}{c}\text { Viewings } \\
\text { / E-book } \\
\text { Ratio }\end{array}$ & $\begin{array}{c}\text { Searches / } \\
\text { E-book } \\
\text { Ratio }\end{array}$ & $\begin{array}{c}\text { Viewings } \\
\text { / Search } \\
\text { Ratio }\end{array}$ \\
\hline 2002 & 2,246 & 1,841 & 1.22 \\
\hline 2003 & 0.99 & 0.98 & 1.34 \\
\hline 2004 & 1.05 & 1.25 & 1.05 \\
\hline 2005 & 2.05 & 1.94 & 1.95 \\
\hline 2006 & 3.17 & 3.28 & 1.11 \\
\hline 2007 & 2.61 & 3.34 & 0.93 \\
\hline 2008 & 1.18 & 1.68 & 0.70 \\
\hline 2009 & 3.63 & 1.48 & 2.46 \\
\hline 2010 & 3.13 & 1.28 & 2.44 \\
\hline
\end{tabular}


ratio may be an indication of a period of collection underusage either because the community the library served had not yet become aware of the resources or the resources simply did not address patron needs. It is a practical numerical starting point based on usage.

In 2002, the library's single e-book (Encyclopedia Britannica Online) yielded a "viewings per e-book" ratio of 2,246 and a "searches per e-book" ratio of 1,841, both of which were the highest "use per e-book" ratios calculated in this study. The fact that the Encyclopedia Britannica Online was the only e-book available to the Laurentian community could partially explain such high ratios. Another equally important possibility could be the search for quick answers. Patrons have always preferred online encyclopedias to their print equivalent. ${ }^{40}$ With a 2005 survey, Roesnita and Zainab ${ }^{41}$ determined that nearly 60 percent of undergraduate students in Malaysia favored the electronic version of a reference book. The same was demonstrated for Chinese students, not only for content user-friendliness but also for the rapidity at which information could be located and retrieved. ${ }^{42}$ The speed at which researchers have found relevant information has been one of the chief reasons for their continued use of online resources. ${ }^{43}$

The "viewings per e-book" ratio dropped sharply the following year to 0.99 , as did the "searches per e-book" ratio to 0.98 (see table 3). These were the lowest ratios calculated. Similar small ratios of 1.05 for viewings and 1.25 for searches were observed in 2004. The increase in collection size after the addition of the COOL titles was not accompanied by an increase in usage. However, in 2005 the viewings and searches ratios doubled; they then tripled in 2006 (see table 3). The ratios did not decrease in value until 2008, when they nearly returned to the values calculated in 2003 and 2004. It is true that the library had resumed the purchase of large consortially negotiated packages, but these low ratios came somewhat as a surprise. Although these e-books were

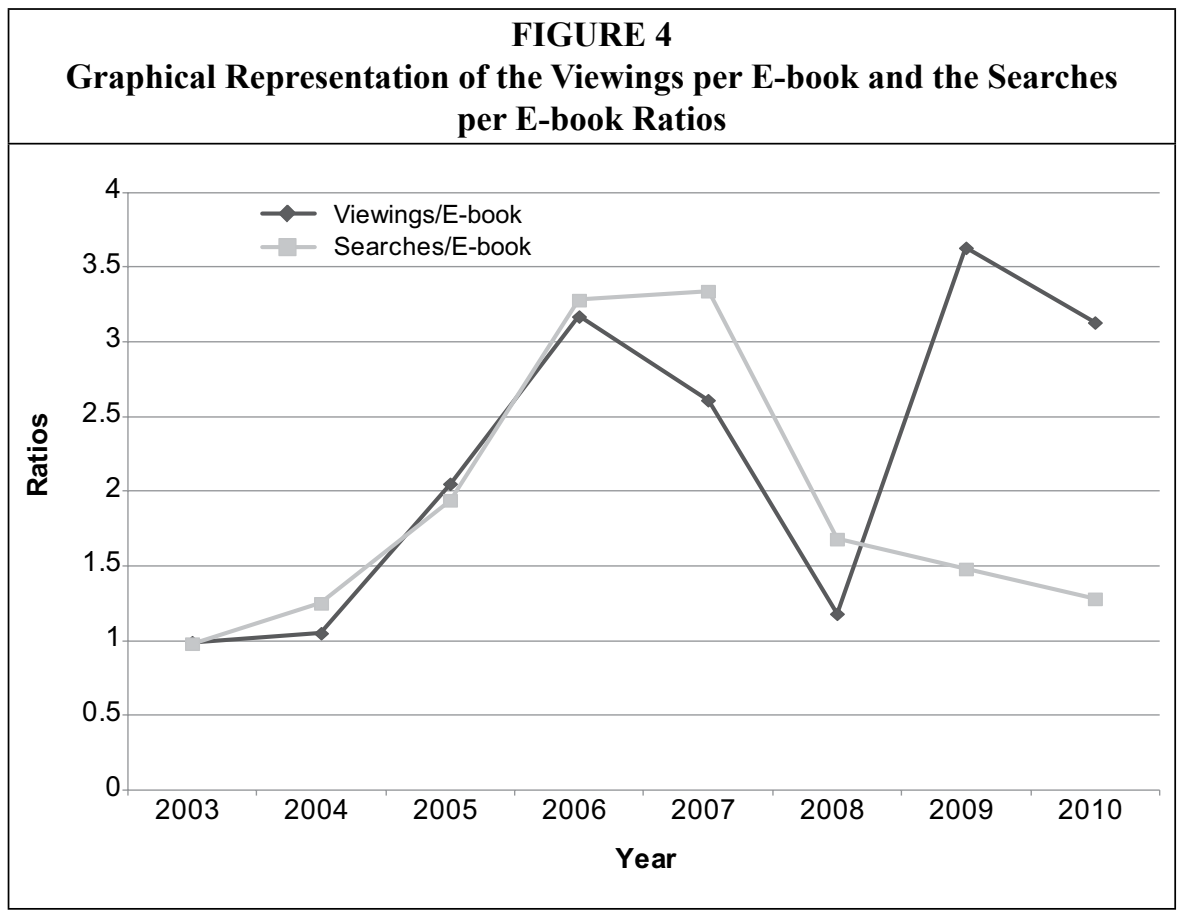


not selected on a title-by-title basis, they were all academic in nature (unlike the COOL packages). Students and faculty were likely ignorant of these new academic additions. Academic communities have taken as much as three years before becoming aware of new online resources unless an aggressive marketing had taken place. $^{44}$

The following two years saw the greatest number of viewings being recorded over the span of this study, leading to the largest "viewings per e-book" ratios, 3.63 in 2009 and 3.13 in 2010. It appeared that the Laurentian University community had taken the better part of a year before using the full value of these academic packages. On the other hand, the "searches per e-book" had not returned to a proportionally high value. In fact, these ratios continued to decrease in value even after the viewings' positive spike (see table 3 and figure 4 ).

As a point of interest, Littman and Connaway $^{45}$ reported a "viewings per e-book" ratio of 3.43 for a total of 14,398 e-books at Duke University Libraries. At the J.N. Desmarais Library, that number of e-books was reached between 2006 and 2007 (see table 2) with similar ratios of 3.17 in 2006 and 2.61 in 2007. Their analysis covered only a 1-year period and would have been worthy of note to see if a further increase in e-book quantity at Duke University would have continued to yield similar "viewings per e-book" ratios.

Plotting the values for "searches per e-book" and "viewings per e-book" ratios together revealed an interesting pattern (see figure 4). The curves closely matched one another until 2009. A Pearson's correlation coefficient of $\mathrm{r}=0.99$ pointed to an extremely strong relationship or association between the two ratios. Searches yielded an equal number of relevant e-book viewings up to 2008 after which a greater number of viewings were connected to fewer searches. In other words, library patrons viewed full-text content at a far greater rate than they were searching. This, again, coincided with the addition of a large number of SpringerLink books.

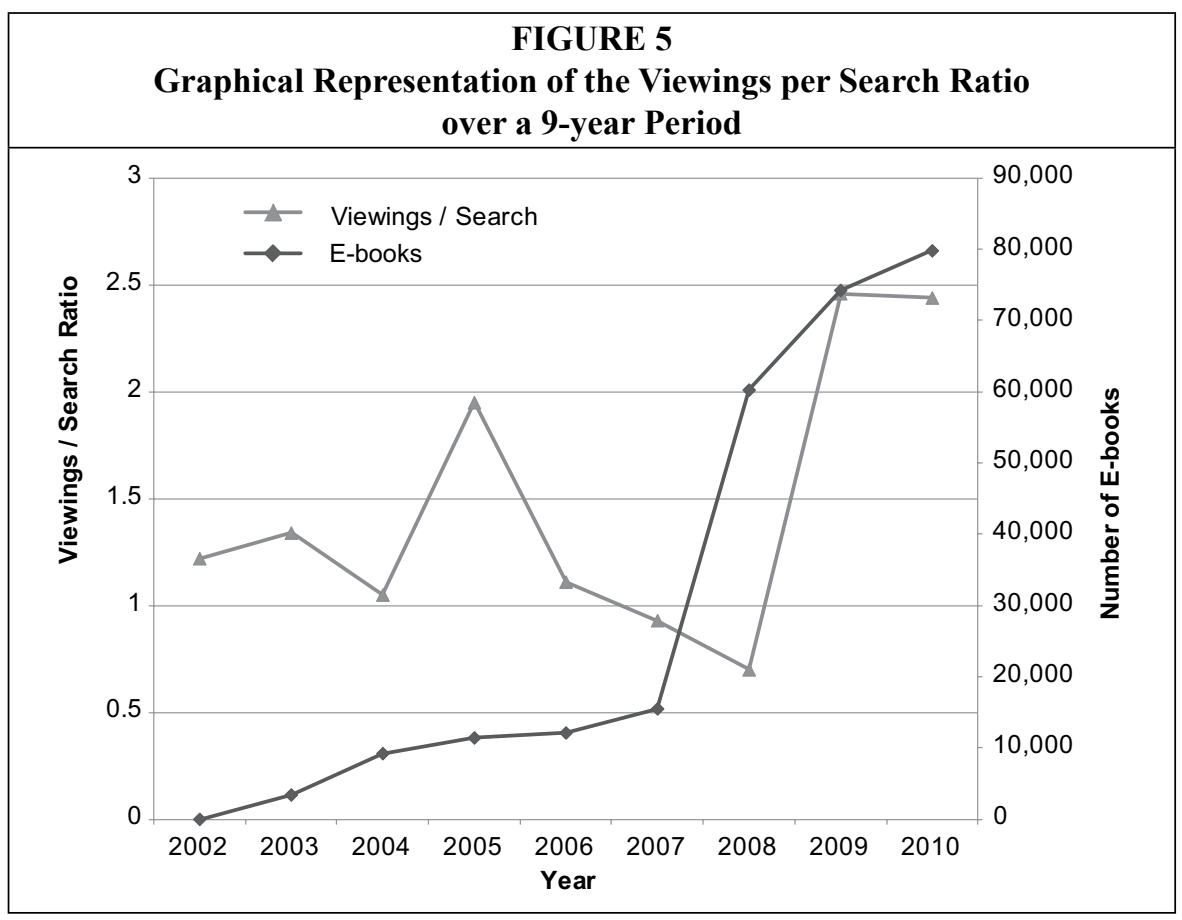


Annual changes in the "viewings per search" ratio with a comparison to the evolution of the e-book collection can be observed in figure 5 . This additional ratio was important in supporting the existence of a link between the amount of searching performed on e-book search engines and the level of full-text content retrieved. It can be used as a relative measure of patron success at extracting content from the collection. The larger the ratio, the more full-text content accessed compared to searches. A very low ratio resulted from patrons performing many searches but extracting little full-text content.

There are two peaks in the "viewings per search" ratio: the first was centered around 2005, and the second ranged between 2009 and 2010. The peak in 2005 corresponded to the phase of collection evolution that saw the library purchasing e-books on a per-title basis. The second peak occurred after the introduction of 50,000 new academic titles to the collection in 2008. Both peaks occurred at the time when the e-book collection experienced the lowest levels of expansion.

As suggested earlier, the smallest ratio, observed in 2008, possibly resulted from such a large volume of new and unfamiliar content added to the library's holdings. Given enough time, patrons will discover the new content as long as it was properly marketed. The near quadrupling of the "viewings per search" ratio the following year suggested patrons had indeed found the content. A consistently low "viewings per search" ratio that was not accompanied by a substantial expansion of the collection could be a good indicator that patron awareness would need to be addressed.

\section{Examining the Impact of the Size and Academic Elements of the Student Population}

The total student population at Laurentian University increased gradually until reaching a peak of 9,100 in 2006 (see table 4). Enrollment numbers steadily decreased over the following two years, reached a low of 8,632 , and rebounded to a total of 9,246 students in 2010 (see table 4). A Pearson's correlation coefficient of $r$ $=0.57$ between the number of viewings and the number of students indicated a positive, albeit weaker, relationship than that calculated between the number of viewings and the number of e-books ( $\mathrm{r}$ $=0.91)$. Similarly, a Pearson's correlation coefficient of $r=0.67$ was calculated between the number of searches and the number of students; again, a much weaker relationship than that observed between the number of searches and the

\begin{tabular}{|c|c|c|c|}
\hline \multicolumn{4}{|c|}{ TABLE 4 } \\
Comparison of the Number of Searches Performed on E-book Vendor \\
Search Engines, the Number of Full-Text Viewings and the Number of \\
Students Enrolled at Laurentian University over a 9-Year Period
\end{tabular}




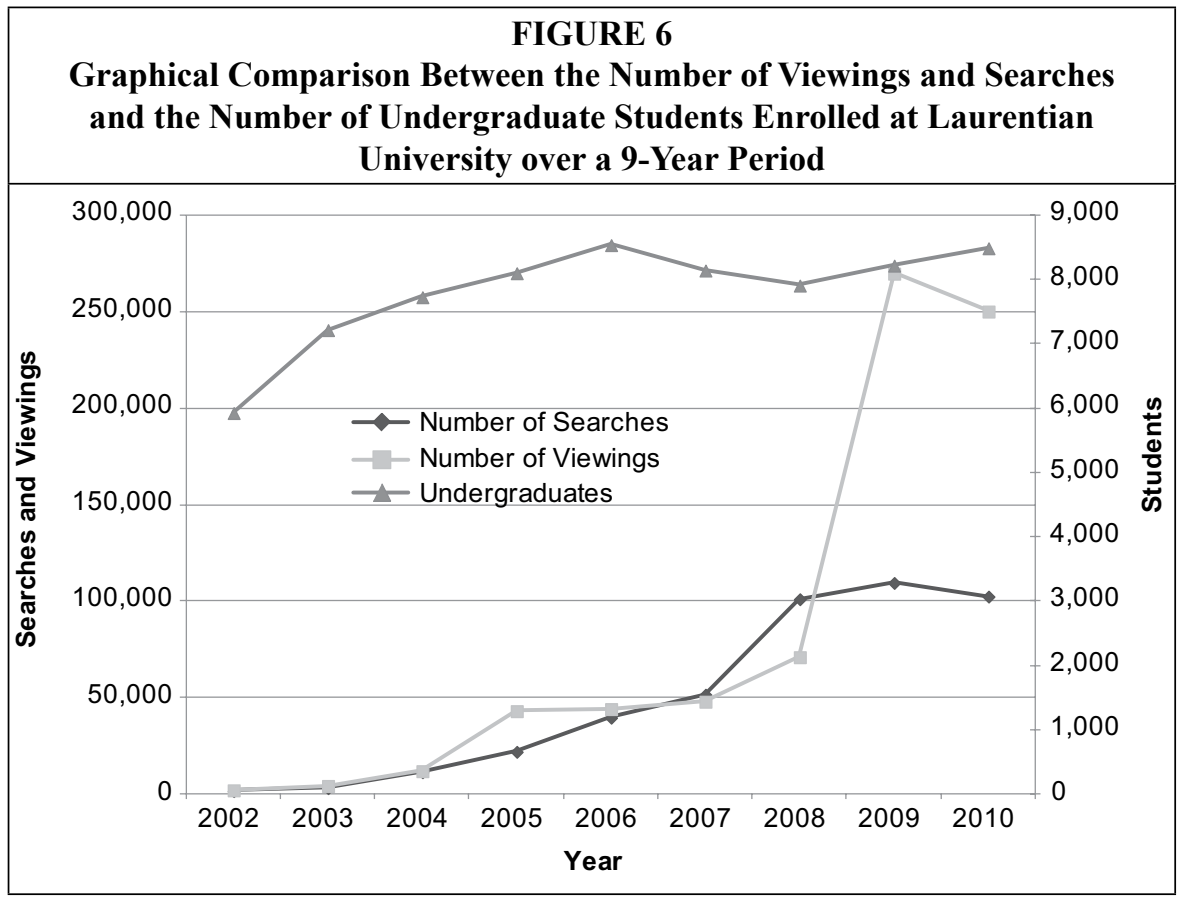

number of e-books $(r=0.96)$. Based on these comparatively large differences in correlation coefficients, it would appear at first glance that the level of e-book usage is more closely associated with the size and content of an e-book collection than to the size of a student population.
The relationship between e-book usage and student population was further examined by dividing students into their academic levels: undergraduate, master's, and doctoral students. As can be observed in figure 6 and table 5, the size of the undergraduate population remained

\begin{tabular}{|c|c|c|c|c|}
\hline \multicolumn{5}{|c|}{$\begin{array}{c}\text { TABLE } 5 \\
\text { Comparison Between the Number of Searches and Viewings and the } \\
\text { Number of Undergraduate Students Enrolled at Laurentian University } \\
\text { over a 9-Year Period }\end{array}$} \\
\hline Year & Searches & Viewings & Undergraduates & $\begin{array}{c}\text { \% Growth in } \\
\text { Undergraduates }\end{array}$ \\
\hline 2002 & 1,841 & 2,246 & 5,932 & $\mathrm{~N} / \mathrm{A}$ \\
\hline 2003 & 3,368 & 4,512 & 7,221 & 22 \\
\hline 2004 & 11,625 & 12,173 & 7,732 & 7 \\
\hline 2005 & 22,190 & 43,269 & 8,105 & 5 \\
\hline 2006 & 39,876 & 44,345 & 8,542 & 5 \\
\hline 2007 & 51,798 & 48,174 & 8,147 & -5 \\
\hline 2008 & 101,262 & 71,226 & 7,913 & -3 \\
\hline 2009 & 109,693 & 269,926 & 8,223 & 4 \\
\hline 2010 & 102,623 & 250,303 & 8,493 & 3 \\
\hline
\end{tabular}


relatively linear, with moderate increases and decreases. The decreases noted in 2007 and in 2008 may have been the result of the largest graduating class Laurentian University had ever witnessed, with 2,090 students receiving diplomas. ${ }^{46}$ Despite a reduction in undergraduate numbers, usage continued to increase with viewings growing by 95 percent from the previous year and searches by 48 percent (see table 2 ). A second upward trend in undergraduate numbers began in 2009 and coincided with the most recent economic downturn. Recessions are often associated with higher college and university enrollments $^{47}$ as unemployment rates climb and people are encouraged to seek either their first or an additional postsecondary education. ${ }^{48}$

A Pearson's correlation coefficient of $r$ $=0.51$ was calculated between the number of undergraduate students and the number of viewings. A coefficient similar in value $(\mathrm{r}=0.59)$ was also calculated between the number of undergraduates and the number of searches. These are very close to the coefficients calculated for the total student population $(r=0.57$ for viewings; $r=0.67$ for searches). The population of undergraduate students at Laurentian University typically com- prised anywhere between 92 percent and 95 percent of the total student body throughout this study. It is, therefore, unsurprising to see the same patterns of growth appear for undergraduates as for the total student populations (see table 4 and table 5). Consequently, it would be expected that the correlation coefficients calculated for the entire study population would be similar to those calculated for undergraduates alone.

Undergraduate student affinity to freely available and nonauthoritative web resources may have influenced the relationship they exhibited regarding e-book usage. The vast majority of undergraduate students would rather use the convenience of the web to find assignmentrelated information instead of exploiting library-purchased authoritative online research tools, especially search engines such as Google. ${ }^{49}$ Schweitzer determined that the majority of undergraduate students preferred Wikipedia as a source of reference. ${ }^{50}$ Some students viewed the credibility of what was found on the web with complete apathy as the timely completion of assignments was far more important. ${ }^{51}$ This attitude appeared to change when the undergraduates approached their final year of study and

\begin{tabular}{|l} 
Comparison Between the Number of Searches and Viewings and the \\
Master's Level and Doctoral Students Enrolled at Laurentian University \\
over a 9-Year Period \\
\hline Year
\end{tabular}


relied more on the library's electronic collection. ${ }^{52}$

The growth of the master's student population was slightly different. Growth was fairly regular until 2007 when it jumped by nearly 50 students (see table 6 and figure 7). After the largest graduating class in Laurentian University's history, it would have been expected that at least some of these graduating students would have applied to join graduate programs. Master's students appeared to have a somewhat closer relationship to the number of viewings and searches than did the undergraduate students. A Pearson's correlation coefficients of $r=0.72$ for viewings and $r=0.92$ for searches were much higher than those calculated for undergraduates. On its own, the strength of a relationship between student and e-book usage should not be interpreted as a confirmation that a particular segment of a student population, undergraduate students in this case, are using e-books at a lower rate than their graduate counterparts. Rather, the strength of a relationship can be used as a mathematical tool to further support existing research that suggest graduate students do use and prefer e-books to the print version. Here, the greater value of $r$ calculated for master's students compared to that calculated for undergraduates would suggest the existence of a tighter association with e-book usage.

In a 2008 study, Nicholas et al. reported that 80 percent of British graduate students used e-books compared to only 62 percent of undergraduates. ${ }^{53}$ Undergraduate studies have been typically driven by class assignments while graduate studies concentrated on research and teaching. ${ }^{54}$ Graduate students have also linked their academic success directly to the quality of the information supplied by their academic library. ${ }^{55}$ Many graduate students also believed that a greater amount of full-text content downloaded or printed would invariably lead to a greater retention of information. ${ }^{56}$ These consumerist attitudes often lead graduates to consider "everything of even a tangential relevance to their theses." ${ }^{57}$

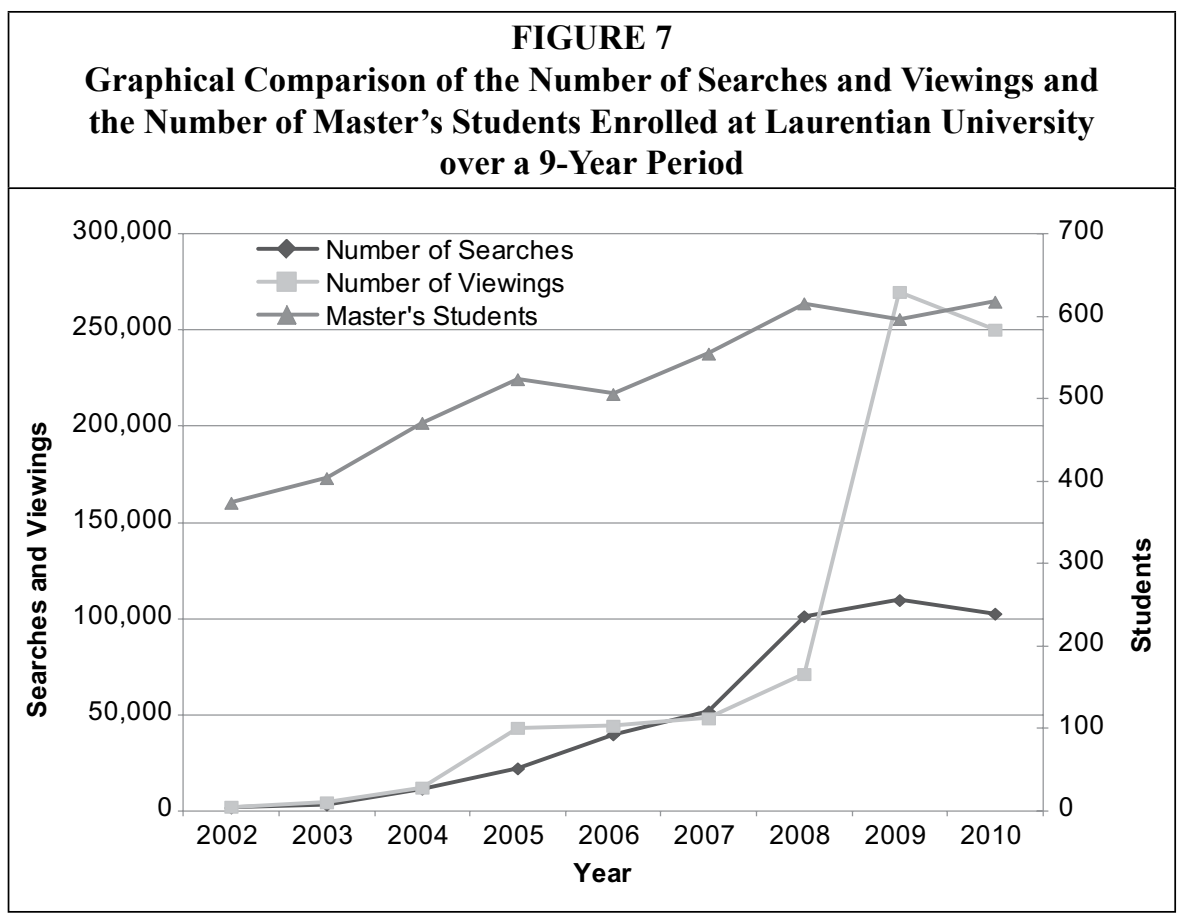




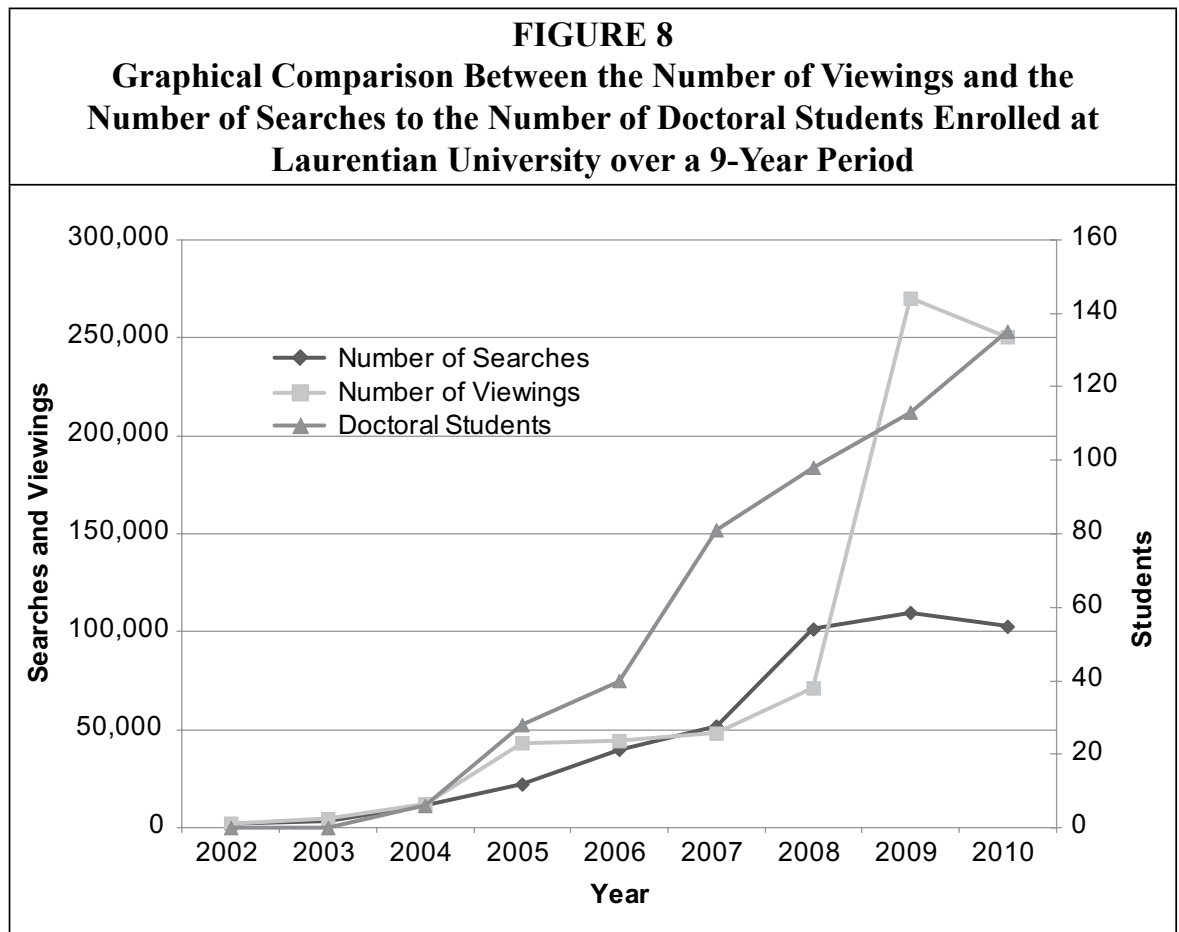

Doctoral student numbers grew more sharply than any other academic segment at Laurentian University (see table 6 and figure 8). Laurentian University offered its first doctoral programs in 2004, in which 6 students enrolled. It was also in 2004 that the number of searches recorded its greatest increase, of 245 percent, compared to 2003. Viewings also recorded a large increase of 170 percent in 2004 and an even greater increase of 255 percent the following year. It was quite possible that such an increase was partly due to the fact that Laurentian University began offering doctoral programs.

The graphical curves comparing the number of searches, viewings, and doctoral students followed one another more closely than those observed for the undergraduate and master's student populations (see figure 8). Furthermore, the Pearson's correlation coefficients of $\mathrm{r}=$ 0.85 for viewings and $r=0.97$ for searches were the largest calculated. Doctoral students numbers demonstrated, by far, the strongest association with e-book usage, even stronger than that observed for master's students. In addition, the 255 percent increase in the number of viewings in 2005 corresponded to the 367 percent increase in doctoral student numbers of the same year. Doctoral students do use ebooks far more than faculty and students of any other academic level. ${ }^{58}$ The design, operation, and management of research projects necessitate much background reading.

\section{Examining the Impact of the Size of the Faculty Population}

Faculty numbers rose steadily until 2009 when the faculty population began to shrink, with a reported net loss of 53 members (see table 7). At that point, the faculty population had returned to its 2005 level. During a 7-year period, faculty numbers have increased fairly consistently and at a similar rate observed for viewings and searches (see figure 9). It was very interesting to observe that the negative change in the size of the faculty population was not translated into a negative change in 
TABLE 7

Comparison in the Number of Searches, the Number of Viewings and the Number of Faculty Members at Laurentian University over a 9-year Period

\begin{tabular}{|c|c|c|c|c|}
\hline Year & Searches & Viewings & Faculty & \% Growth \\
\hline 2002 & 1,841 & 2,246 & 320 & N/A \\
\hline 2003 & 3,368 & 4,512 & 331 & 3 \\
\hline 2004 & 11,625 & 12,173 & 358 & 8 \\
\hline 2005 & 22,190 & 43,269 & 377 & 5 \\
\hline 2006 & 39,876 & 44,345 & 401 & 6 \\
\hline 2007 & 51,798 & 48,174 & 427 & 6 \\
\hline 2008 & 101,262 & 71,226 & 432 & 1 \\
\hline 2009 & 109,693 & 269,926 & 379 & -12 \\
\hline 2010 & 102,623 & 250,303 & 365 & -4 \\
\hline
\end{tabular}

the number of viewings and searches. Even more interesting was the similarity between the 4 percent decrease in faculty numbers observed in 2010 and the 6 percent decrease in searches and the 7 percent decrease in viewings for the same period (see figure 9, table 7, and table 2).

Pearson's correlation coefficients of $r=$ 0.14 for viewings and $\mathrm{r}=0.57$ for searches represented a much weaker relationship between the faculty numbers and total e-book usage and were the lowest correlation coefficients calculated for all variables examined in this study. Moreover, a coefficient of $r=0.14$ reflected the lack of any relationship whatsoever..$^{59}$ The size of the faculty population demonstrated the weakest association with the level of

\section{FIGURE 9}

Graphical Comparison of the Number of Searches and Viewings and the Number of Faculty Members at Laurentian University over a 9-Year Period

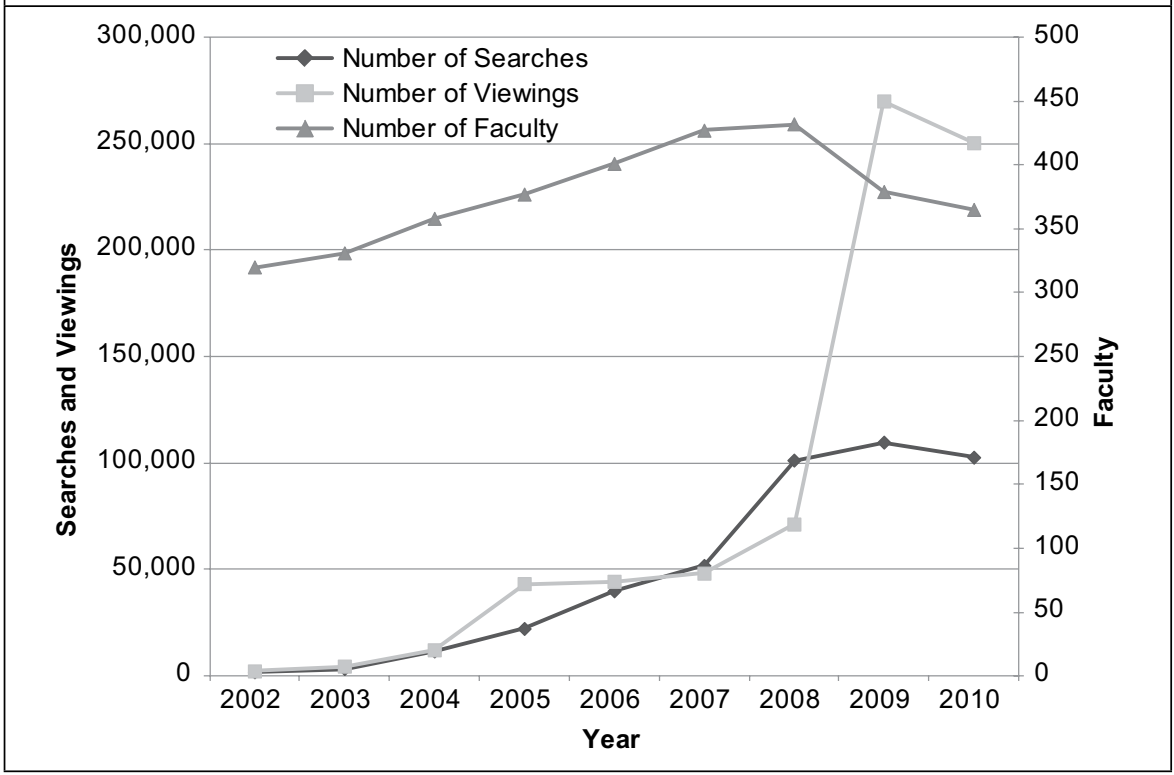


e-book usage at Laurentian University. Although a very weak relationship between faculty numbers and e-book usage figures does not, in itself, demonstrate that faculty members do not use e-books, or use them far less than their students, the weak relationship does tie in with studies reporting the low acceptance of e-books by university faculty.

Faculty influence on e-book usage levels had been mixed in the literature. Shelburne reported that 60 percent of faculty at the University of Illinois used e-books, which was about the same percentage of graduate and undergraduate students. ${ }^{60}$ On the other hand, Shen effectively demonstrated that faculty members used ebooks far less than their students. ${ }^{61}$ In fact, students have always been "heavier users of e-books than their teachers." ${ }^{\prime 2}$ Faculty members also preferred print books to their electronic equivalents. ${ }^{63}$ Those who have used e-books have done so only occasionally. ${ }^{64}$ Foote and Rupp-Serrano further determined that 33 percent of faculty members at the University of Oklahoma have used e-books compared to 44 percent of graduate students. ${ }^{65}$ And Camacho and Spackman found that over 60 percent of faculty members at Brigham Young University strongly preferred print books to any other medium. ${ }^{66}$

\section{Conclusions}

The size of the e-book collection at the J.N. Desmarais Library increased greatly over the years. From a single e-book in 2002, it grew to 79,821 by the end of 2010 . The pattern of purchase was marked by four phases, changing from one of bulk purchasing to that of a more selective acquisition of individual titles and then back to the bulk purchasing of large ebook collections.

Searches could also act as a feasible metric to measure usage of an e-book collection rather than relying entirely on viewing numbers. A Pearson's correlation coefficient of $r=0.80$ indicated a strong relationship between the two variables. A Student's t-Test further confirmed the lack of significant difference between searches and viewings numbers recorded in this study. As vendors tend to report viewings in different ways, relying on an alternative usage metric can be prudent and sensible. But given the choice, full-text viewings should be the preferred metric as it represents the true value of e-book usage and reflect actual patron access to and use of information.

Very high Pearson's correlation coefficients were calculated for viewings $(r$ $=0.91)$ and searches $(r=0.96)$ in relation to the number of e-books. This would suggest the importance of the size of an e-book collection on its usage. However, the slight drop in viewings and searches in 2010 compared to the previous year may also be an indication that a critical mass of e-books had been achieved and any further large increases in collection size may be a needless expenditure. As the library intends to continue to purchase additional e-books, both in large consortially negotiated packages as well as on a per-title basis, the continued monitoring of both collection size and usage levels during the coming years will be important.

Large "viewings per e-book" and "searches per e-book" ratios were observed when e-books were purchased selectively, on a title-by-title basis. However, it should not yet be concluded that a more selective method of purchase would necessarily be accompanied by an increase in e-book usage. In fact, 2009 and 2010 recorded the largest usage ratios, even with the large bulk purchases in 2008 . The difference was that these acquisitions were strictly academic in nature. The low ratio in 2008 may simply have resulted from a temporary lack of awareness on the part of the university community. A "viewings per search" ratio may also prove to be a good indicator of patron success rate at finding relevant full-text content in an e-book collection.

Based on the relative relationship strengths, doctoral student numbers demonstrated the strongest association with e-book usage, followed closely by mas- 
ter's students. On the other hand, faculty and undergraduate students expressed the weakest relationships with e-book usage. It is clear that, when examining the effect of student numbers on usage, it is important to compare these numbers by academic level as each exhibited different patterns of association.

\section{Further Research}

A deeper quantitative analysis of e-book usage would be desirable. The general patterns and interactions are an important beginning, but it would be just as important to continue the analysis into the possible links between individual academic program size and usage.

A comparison between usage levels for electronic reference material and monographic books will also be examined.

It would be of further value to determine if the patterns of use and relationships reported in this paper would also be observed at other institutions of higher learning, not only those similar in size and structure to Laurentian University but also those with smaller or larger populations.

\section{Notes}

1. Laurentian University is a multicampus university founded in 1960 , with its main campus located in Sudbury, Ontario, Canada. It is considered by the Carnegie classification of institution scale (Carnegie Foundation for the Advancement of Teaching 2011) to be medium in size with a total full-time student population of 9,200 in 2010 and more than 600 enrolled in various graduate programs. Also in 2010, more than 365 full-time faculty members taught and performed research. Programs cover multiple fields in the sciences, social sciences, and humanities with 94 undergraduate, 18 master's, and 6 doctoral degrees offered.

2. V. Owen, R. Tiessen, L. Weir, D. DesRochers, and W. Noel, “E-Books in Research Libraries: Issues of Access and Use," Canadian Association of Research Libraries Copyright Committee, Task Group on E-Books, available online at www.carl-abrc.ca/projects/copyright/pdf/CARL EBook Report-e.doc [accessed 15 July 2001].

3. A. Soderback, "Infrastructure First! E-Books and Academic Libraries in Sweden," Serials 24, no. 1 (2011): 38-42.

4. K.T. Anuradha and H.S. Usha, "E-books Access Models: An Analytical Comparative Study," The Electronic Library 24, no. 5 (2006): 662-79; F. Bry and M. Krause, "Perspectives for Electronic Books in the World Wide Web Age,"

The Electronic Library 20, no. 4 (2002): 275-87; L.S. Connaway, "A Web-Based Electronic Book (E-Book) Library: The netLibrary Model," Library Hi Tech 19, no. 4 (2001): 340-49; D. Dillon, “E-books: The University of Texas Experience, Part 1," Library Hi Tech 19, no. 2 (2001): 113-24.

5. J. Dearnley, C. McKnight, and A. Morris, "Electronic Book Usage in a Public Library: A Study of User and Staff Reactions to a PDA-based Collection," Journal of Librarianship and Information Science 36, no. 4 (2004): 175-82.

6. J.B. Foote and K. Rupp-Serrano, “Exploring E-book Usage Among Faculty and Graduate Students in the Geosciences: Results of a Small Survey and Focus Group Approach," Science and Technology Libraries 29, no. 3 (2010): 216-34; D. Nicholas, I. Rowlands, and H.R. Jamali, "E-textbook Use, Information Seeking Behaviour and Its Impact: Case Study Business and Management," Journal of Information Science 36, no. 2 (2010): 263-80; I. Rowlands, D. Nicholas, H.R. Jamali, and P. Huntington, "What Do Faculty and Students Really Think about E-books," Aslib Proceedings: New Information Perspectives 59, no. 6, (2007): 489-511; I. Roesnita and A.N. Zainab, "The Pattern of E-book Use amongst Undergraduates in Malaysia: A Case of to Know Is to Use," Malaysian Journal of Library and Information Science 10, no. 2 (2005): 1-23.

7. M. Levine-Clark, "Electronic Books and the Humanities: A Survey at the University of Denver," Collection Building 26, no. 1 (2007): 7-14; T.P. Bailey, "Electronic Book Usage at a Master's Level I University: A Longitudinal Study," Journal of Academic Librarianship 32, no. 1 (2006): 52-59; M. Langston, "The California State University E-book Pilot Project: Implications for Cooperative Collection Development," Library Collections, Acquisitions, and Technical Services 27, no. 1 (2003): 19-32; Dillon, "E-books: The University of Texas Experience, Part 1," 113-124; S. Gibbons, "Growing Competition for Libraries," Library Hi Tech 19, no. 4 (2001): 363-67.

8. Foote and Rupp-Serrano, "Exploring E-book Usage," 216-34.

9. D. Nicholas, I. Rowlands, D. Clark, P. Huntington, H.R. Jamali, and C. Olle, “UK Scholarly E-book Usage: A Landmark Survey," Aslib Proceedings: New Information Perspectives 60, no. 4 (2008): 
311-34.

10. C. Armstrong, "Books in a Virtual World: The Evolution of the E-book and Its Lexicon," Journal of Librarianship and Information Science 40, no. 3 (2008): 193-205; M. Tripathi and V.K.J. Jeevan, "E-book Subscription in a Distance Education Institution: A Case of Indira Gandhi National Open University, India," Serials Review 34, no. 2 (2008): 104-14; A. Dinkelman and K. Stacy-Bates, "Accessing E-books through Academic Library Web Sites," College and Research Libraries 68, no. 1 (2007): 45-58; Anuradha and Usha, "E-books Access Models,, 662-79; J.E. Gall, "Dispelling Five Myths about E-books," Information Technology and Libraries 24, no. 1 (2005): 25-31; S.S. Rao, "Electronic Books: Their Integration into Library and Information Centers," The Electronic Library 23, no. 1 (2005): 116-40; S.A. Long, "The Case of E-books: An Introduction," New Library World 104, no. 1/2 (2003): 29-32; S.K. Sawyer, "Electronic Books: Their Definition, Usage and Role in Libraries," Libres: Library and Information Science Research 12, no. 2 (2002), available online at http:// libres.curtin.edu.au/libres12n2/ebooks.htm [accessed 6 July 2011].

11. M. Tripathi and V.K.J. Jeevan, "E-book Subscription in a Distance Education Institution: A Case of Indira Gandhi National Open University, India," 104-14; P. Hernon, R. Hopper, M.R. Leach, L.L. Saunders, and J. Zhang, "E-book Use by Students: Undergraduates in Economics, Literature, and Nursing," Journal of Academic Librarianship 33, no. 1 (2007): 3-13; S.A. Long, "The Case for E-books: An Introduction," 29-32; D.T. Hawkins, "Electronic Books: A Major Publishing Revolution," Online 24, no. 4 (2000): 14-28.

12. Gall, "Dispelling Five Myths about E-books," 25-31.

13. A. McLuckie, "E-books in an Academic Library: Implementation at the ETH Library, Zurich," Electronic Library 23, no. 1 (2005): 92-102; C. Lynch, "The Battle to Define the Future of the Book in the Digital World," First Monday 6, no. 6 (2001), available online at www.uic.edu/htbin/ cgiwrap/bin/ojs/index.php/fm/article/view/864/773 [accessed 1 September 2011].

14. H. Chu, "Electronic Books: Viewpoints from Users and Potential Users," Library Hi Tech 21, no. 3 (2003): 340-46.

15. S.S. Rao, "Electronic Books: Their Integration into Library and Information Centers," 116-40.

16. J.I. Balas, "Developing Library Collections for a Wired World," Computers in Libraries 20, no. 6 (2000): 61-63; E.L. Morgan, "Electronic Books and Related Technologies," Computers in Libraries 19, no. 10 (1999): 36-39.

17. Institutional Planning Office, Sudbury, ON: Laurentian University (2011), available online at www.laurentian.ca/Laurentian/Home/Departments/Institutional+Research/Other/Graduates/ Graduates.htm?Laurentian_Lang=en-CA [accessed 6 July 2011].

18. D.D. Blecic, J.B. Fiscella, and S.E. Wiberley, Jr, "Measurement of Use of Electronic Resources: Advances in Use Statistics and Innovations in Resource Functionality," College and Research Libraries 68, no. 1 (2007): 26-44.

19. B.F. Pendleton, "Ratio Correlation," in Encyclopedia of Statistical Sciences. Volume 10: Preference Mapping to Recovery Interblock Information (Hoboken, N.J.: Wiley Interscience, 2005): 6967-71.

20. J. Far, Biostatistical Analysis (Upper Saddle River, N.J.: Prentice Hall, 2010).

21. R.R. Sokal and F.J. Rohlf, Biometry (New York: W.H. Freeman and Company, 1981).

22. Southern Ontario Library Services, "What Is COOL?," (2011), available online at www. sols.org/resourcesharing/coolcpa/whatiscool.htm [accessed 30 June 2011]; A. Dorsey, "Advocating Co-operation: The Consortium of Ontario Libraries (COOL)," Access 12, no. 2 (2006): 34-35.

23. OCUL, "OCUL Constitution," (2011), available online at www.ocul.on.ca/view.php?id=1079 [accessed 23 June 2011]; M. Scigliano, "Consortium Purchases: Case Study for a Cost-Benefit Analysis," Journal of Academic Librarianship 28, no. 6 (2002): 393-99.

24. CRKN, "Mission Statement and Goal" (2011), available online at www.researchknowledge. ca/en/about/mission_statement.jsp [accessed 30 June 2011].

25. Soderback, "Infrastructure First!" 38-42; R. Croft and C. Davis, "E-Books Revisited: Surveying Student E-Book Usage in a Distributed Learning Academic Library 6 Years Later," Journal of Library Administration 50, no. 5/6 (2010): 543-69; Bailey, "Electronic Book Usage," 52-59.

26. S. Harris, "Ebooks Help Tackle Information Mountain," Research Information 51 (Dec. 2010/ Jan. 2011): 22-24.

27. NetLibrary, "Sharing an eBook collection the COOL way: Ontario-area Consortium and OCLC Canada Develop Flexible Program So Multiple Libraries Can Share Collection without Large Investment" (2005), available online at www.sols.org/resourcesharing/coolcpa/cooldata/ NetLibraryCaseStudyCOOL.pdf [accessed 6 June 2011].

28. S. Gibbons, NetLibrary eBook Usage at the University of Rochester Libraries, (2001), available online at www.lib.rochester.edu/main/ebooks/analysis.pdf [accessed 6 July 2011].

29. R. Slater, "Ebooks or Print Books, "Big Deals" or Local Selections: What Gets More Use?" Library Collections, Acquisitions, and Technical Services 33, no. 1 (2009): 59-72; N. Sprague and B. Hunter, "Accessing Ebooks: Taking a Closer Look at Ebook Statistics," Library Collections, Acquisi- 
tions and Technical Services 32, no. 3/4 (2008): 150-57.

30. T. Bucknell, "The 'Big-Deal' Approach to Acquiring E-books: A Usage-Based Study," Serials 23, no. 2 (2010): 126-34; C.S. Herlihy and H. Yi, "E-books in Academic Libraries: How Does Currency Affect Usage?" New Library World 111, no. 9/10 (2010): 371-80; W.A. Shelburne, "E-book Usage in an Academic Library: User Attitudes and Behaviors," Library Collections, Acquisitions, and Technical Services 33, no. 2/3 (2009): 59-72; D. Baker, "Inside Every Fat Man: Balancing the Digital Library Budget," Interlending and Document Supply 36, no. 4 (2008): 213-17; D.M. Carlock and A.M. Perry, "Exploring Faculty Experiences with E-books: a focus group," Library Hi Tech 26, no. 2 (2008): 244-54.

31. G. Coker, "Usability in Emerging E-content Environments," Information Services and Use 27 (2007): 179-84. 41-49.

32. J.E. Grogg and B. Ashmore, "Riding the eBook Wave," Against the Grain 17, no. 1 (2005):

33. A.K. Shrimplin, A. Revelle, S. Hurst, and K. Messner, “Contradictions and Consensus: Clusters of Opinions on E-Books," College and Research Libraries 72, no. 2 (2011): 181-90; C. Simon, "Just the Facts: An Examination of E-Book Usage by Business Students and Faculty," The Reference Librarian 52, no. 3 (2011): 263-73; N. Gielen, "Handheld E-Book Readers and Scholarship: Report and Reader Survey," ACLS Humanities E-Book White Paper No. 3 (New York: The American Council of Learned Societies, 2010), available online at www.humanitiesebook.org/heb-whitepaper-3.html [accessed 14 July 2011]; Nicholas, Rowlands, and Jamali, "E-textbook Use, Information Seeking Behaviour and Its Impact," 263-80; D. Nicholas, P. Huntington, H.R. Jamali, I. Rowlands, and M. Fieldhouse, "Student Digital Information-Seeking Behaviour in Context," Journal of Documentation 65, no. 1 (2009): 106-32; E. Schnittman, "Discoverability and Access in Book Publishing: Longtail Marketing and Content Access Models Explored," Publishing Research Quarterly 24 (2008): 139-42; M. Levine-Clark, "Electronic Book Usage: A Survey at the University of Denver," portal: Libraries and the Academy 6, no. 3 (2006): 285-89; Dillon, "E-books: The University of Texas Experience, Part $1, " 113-24$.

34. Coker, "Usability in Emerging E-content Environments," 179-84.

35. Foote and Rupp-Serrano, "Exploring E-book Usage," 216-34; Chu, "Electronic Books: Viewpoints from Users and Potential Users," 340-46.

36. Foote and Rupp-Serrano, "Exploring E-book Usage," 216-34; P. Hernon, R. Hopper, M.R. Leach, L.L. Saunders, and J. Zhang, "E-book Use by Students: Undergraduates in Economics, Literature, and Nursing," Journal of Academic Librarianship 33, no. 1 (2007): 3-13.

37. Harris, "Ebooks Help Tackle Information Mountain," 22-24.

38. Gibbons, NetLibrary eBook Usage at the University of Rochester Libraries.

39. Herlihy and Yi, "E-books in Academic Libraries" 371-80.

40. M. Ramaswamy, T. Baillargeon, and C.N. Simser, "Making E-Reference Books Findable," Library Philosophy and Practice 10, no. 1 (2008): 1-10; E. Safley, "Demand for E-books in an Academic Library," Journal of Library Administration 45, no. 3/4 (2006): 445-57.

41. Roesnita and Zainab, "The Pattern of E-book Use Amongst Undergraduates in Malaysia," 1-23.

42. H.-L. Jian, R.E. Sandnes, K.M.Y. Law, Y.-P. Huang, and Y.-M. Huang, "The Role of Electronic Pocket Dictionaries as an English Learning Tool among Chinese Students," Journal of Computer Assisted Learning 25, no. 6 (2009): 503-14.

43. C.A. Hughes and N.L. Buchanan, "Use of Electronic Monographs in the Humanities and Social Sciences," Library Hi Tech 19, no. 4 (2001): 368-75; W. Sewell and S. Teitelbaum, "Observations of End-User Online Searching Behavior Over Eleven Years," Journal of the American Society for Information Science 37, no. 4 (1986): 234-45.

44. J. Luther, "White Paper on Electronic Journal Usage Statistics," Serials Librarian 41, no. 2 (2001): 119-47; C.T. Townley and L. Murray, "Use-Based Criteria for Selecting and Retaining Electronic Information: A Case Study," Information Technology and Libraries 18, no. 1 (1999): 32-39.

45. J. Littman and L.S. Connaway, "A Circulation Analysis of Print Books and E-Books in an Academic Research Library," Library Resources and Technical Services 48, no. 4 (2004): 256-62.

46. Institutional Planning Office (2011).

47. J.A. Douglass and University of California, "From Chaos to Order and Back? A Revisionist Reflection on the California Master Plan for Higher Education@50 and Thoughts about Its Future," CSHE: Research and Occasional Paper Series 7, no. 10 (2010): 1-20; S. Bushon, "Community-College Enrollments Are Up, But Institutions Struggle to Pay for Them," Chronicles of Higher Education 55, no. 20 (2009): A24.

48. R. Samitamana, Business Cycles and Postsecondary School Enrollment (Ph.D. dissertation, 2009).

49. D.K. Swain, "Students' Keenness on Use of E-resources," The Electronic Library 28, no. 4 (2010): 580-91; M. O’Farrell and J. Bates, "Student Information Behaviours during Group Projects: A Study of LIS Students in University College Dublin, Ireland," Aslib Proceedings: New Informa- 
tion Perspectives 61, no. 3 (2009): 302-15; H.L. Lee, "Information Structures and Undergraduate Students," Journal of Academic Librarianship 34, no. 3 (2008): 211-19; P. Mabrouk, R. McIntyre, M. Virrankoski, and K. Jeliffe, "WebGURU: The Web-Based Guide to Research for Undergraduates," Journal of College Science Teaching 36, no. 7 (2007): 18-23; E. Sexton, "Journal Use by Graduate Students as Indicated by Master's Theses Bibliographies at an Urban Commuter College, 1991-2004," Behavioral and Social Sciences Librarian 24, no. 2 (2006): 93-111; J.R. Griffiths and P. Brophy, "Student Searching Behavior and the Web: Use of Academic Resources and Google," Library Trends 53, no. 4 (2005): 539-54.

50. N.J. Schweitzer, "Wikipedia and Psychology: Coverage of Concepts and Its Use by Undergraduate Students," Teaching of Psychology 35, no. 2 (2008): 81-85.

51. M. Karas and R. Green, "The Information Needs and Information-Seeking Behaviors of Community College and Lower-Division Undergraduate Students," Community and Junior College Libraries 14, no. 2 (2007): 103-09.

52. J.E. Callinan, "Information-Seeking Behaviour of Undergraduate Biology Students," Library Review 54, no. 2 (2005): 86-99.

53. Nicholas, Rowlands, Clark, Huntington, Jamali, and Olle, “UK Scholarly E-book Usage: A Landmark Survey," 311-34.

54. R. Wallach, "From Google Books to Library Catalogs: A Consumerist Exploration of Information Literacy for Graduate Students in Slavic Studies," Slavic and East European Information Resources 10, no. 2/3 (2009): 221-34.

55. M.A. Jankowska, K. Hertel, and N.J. Young, "Improving Library Service Quality to Graduate Students: LibQual $+{ }^{\mathrm{TM}}$ Survey Results in a Practical Setting," portal: Libraries and the Academy 6, no. 1 (2006): 59-77; C.B. Wenger, "The Value of Multiple Database Searching to Scholarly Research Productivity," Science and Technology Libraries 23, no. 1 (2002): 17-29.

56. A.L. O'Neill, "A (Very) Concise History of the Impact of Electronic Journals on Graduate Students," Serials Librarian 26, no. 1 (1995): 13-15.

57. Wallach, "From Google Books to Library Catalogs," 221-34.

58. S. Lewis, "E-Book Discovery and Use Behaviour Is Complex," Evidence Based Library and Information Practice 3, no. 2 (2008): 38-41. 1988).

59. J. Cohen, Statistical Power Analysis for the Behavioral Sciences (New York: Routledge Academic,

60. Shelburne, “E-book Usage in an Academic Library," 59-72.

61. J. Shen, "The E-Book Lifestyle: An Academic Library Perspective," The Reference Librarian 52, no. $1 / 2$ (2011): 181-89.

62. Nicholas, Rowlands, Clark, Huntington, Jamali, and Olle, "UK Scholarly E-Book Usage: A Landmark Survey," 311-34.

63. Ebrary, 2007 Global Faculty Survey E-book Survey (2007), available online at www.ebrary. com/corp/collateral/en/Survey/ebrary_eBook_survey_2007.pdf [accessed 14 July 2011]; E.W. Walton, "Faculty and Student Perceptions of Using E-books in a Small Academic Institution," ACRL Thirteenth National Conference Proceedings, Baltimore, MD (Chicago: American Library Association, 2007), available online at www.ala.org/ala/mgrps/divs/acrl/events/national/baltimore/papers/92. pdf [accessed 14 July 2011]; J. Cox, "E-books: Challenges and Opportunities," D-Lib Magazine 10, no. 10 (2004), available online at www.dlib.org/dlib/october04/10contents.html [accessed 11 July 2011].

64. Levine-Clark, "Electronic Book Usage," 285-89.

65. Foote and Rupp-Serrano, "Exploring E-book Usage," 216-34.

66. L. Camacho and A. Spackman, "Transitioning to E-books: Usage and Attitudes among Business Faculty," Journal of Business and Finance Librarianship 16, no. 1 (2011): 33-45. 